\title{
Relationships between body condition, body condition loss, and serum metabolites during the transition period in primiparous and multiparous cows
}

\author{
Tanja Gärtner, ${ }^{1}$ Erhard Gernand, ${ }^{2}$ Jutta Gottschalk, ${ }^{3}$ and Karsten Donat ${ }^{1,4 *}$ \\ ${ }^{1}$ Animal Health Service, Thuringian Animal Diseases Fund, Victor-Goerttler-Straße 4, 07745 Jena, Germany \\ ${ }^{2}$ Department of Animal Husbandry, Thuringian State Institute for Agriculture, Naumburger Straße 98, 07743 Jena, Germany \\ ${ }^{3}$ Institute of Physiological Chemistry, Faculty of Veterinary Medicine, University of Leipzig, An den Tierkliniken 1, D-04103 Leipzig, Germany \\ ${ }^{4}$ Clinic for Obstetrics, Gynecology and Andrology with Veterinary Ambulance, Justus-Liebig-University Giessen, Frankfurter Straße 106, \\ 35392 Giessen, Germany
}

\section{ABSTRACT}

In the transition period from late gestation to early lactation, dairy cows undergo tremendous metabolic changes. Insulin is a relevant antilipolytic factor. Decreasing serum concentrations of insulin and glucose, increasing serum concentrations of nonesterified fatty acids (NEFA) and $\beta$-hydroxybutyrate (BHB), and changes in body condition score (BCS) reflect the negative energy balance around calving. This study investigated peripartum metabolic adaptation in 359 primiparous and 235 multiparous German Holstein cows from a commercial dairy herd under field conditions. Body condition score was recorded and blood samples were taken 10 to $1 \mathrm{~d}$ prepartum, 2 to $4 \mathrm{~d}$ postpartum, and 12 to $20 \mathrm{~d}$ postpartum. Generalized mixed models and generalized estimation equations were applied to assess associations between prepartum BCS; BCS changes during the transition period; insulin, glucose, NEFA, and BHB serum concentrations; and milk yield, which was taken from an electronic milk meter from d 6 of lactation. Serum insulin concentrations of multiparous postpartum cows were lower compared with prepartum, and compared with primiparous cows. In general, primiparous cows had lower postpartum NEFA and BHB concentrations than multiparous cows. In primiparous cows, we identified a positive association between prepartum BCS and prepartum serum insulin concentration. Prepartum obese multiparous cows, but not primiparous cows, were characterized by higher postpartum serum NEFA and BHB concentrations and lower milk yield than other cows in the same parity class. Primiparous cows with a smaller degree of BCS

Received September 28, 2018.

Accepted June 4, 2019.

*Corresponding author: kdonat@thueringertierseuchenkasse.de loss during the transition period had higher postpartum insulin and lower NEFA concentrations and lower milk yield than other primiparous cows. In conclusion, primiparous cows had less lipolysis and lower milk yield than multiparous cows, associated with higher insulin concentrations. Avoiding high body condition loss during the transition period is a main factor in preventing peripartal metabolic imbalances of glucose and fat metabolism.

Key words: fat mobilization, lipolysis, insulin

\section{INTRODUCTION}

During the transition period, high-yielding dairy cows are faced with tremendous metabolic changes. At transition from pregnancy to lactation, the channeling of nutrients to the fetus and mammary glands is challenging (Bell, 1995). Glucose is the most important substrate for milk production (De Koster and Opsomer, 2013), and insulin is a key regulator of lipid metabolism and glucose uptake by peripheral cells. In general, an increase in serum concentrations of nonesterified fatty acids (NEFA) and BHB, as well as decreased serum concentrations of insulin and glucose, are indicators of negative energy balance (Han van der Kolk et al., 2017). The degree of fat mobilization varies during the transition period. In a German study that classified cows by mean total liver fat concentrations as low- and high-fat-mobilizing cows, the low-fat-mobilizing group had the highest hepatic glycogen concentrations and serum insulin concentrations postpartum, whereas the high-fat-mobilizing group was characterized by enhanced plasma concentrations of NEFA and BHB (Weber et al., 2013a).

A link between prepartum body condition, fat mobilization, and postpartum serum insulin concentration has been demonstrated in several studies (Weber et al., 2013a,b; De Koster et al., 2015; Rico et al., 2015). Feeding cows a high-energy prepartum diet has been 
associated with higher serum insulin concentrations (Goerigk at al., 2010; Ji et al., 2012), and overweight cows had a greater loss in body condition and higher serum concentrations of glucose, insulin, and NEFA from $45 \mathrm{~d}$ prepartum to $4 \mathrm{~d}$ postpartum (Rico et al., 2015). As part of physiological adaptation to lactation in dairy cows, postpartum pancreatic insulin secretion was lower than prepartum (Weber et al., 2016), leading to lower basal insulin concentrations (Meikle et al., 2004; Wathes et al., 2007; Goerigk et al., 2010; Zachut et al., 2013; Mann et al., 2016). Based on glucose tolerance test results, Salin et al. (2017) suggested that an increase in whole-body insulin sensitivity might be of minor importance relative to the change in insulin secretion and clearance during the transition period. Furthermore, the lactating mammary gland's insulinindependent glucose consumption leads to greater glucose clearance, making clear conclusions about peripheral insulin sensitivity difficult (Bossaert et al., 2008).

Most of the studies that investigated insulin serum concentration in the context of fat and glucose metabolism used multiparous cows in their experiments; less information is available on differences in insulinregulated lipid and energy metabolism between multiparous and primiparous cows. The available studies, which included primiparous cows and their multiparous herd mates and evaluated metabolic variables of energy balance with respect to body condition, showed variable results (Meikle et al., 2004; Wathes et al., 2007; Ruprechter et al., 2018). Considering that primiparous cows represent a high proportion of cows in production, a better understanding of the metabolic situation during the transition period around first parturition is necessary.

For this reason, we studied the associations between prepartum body condition and change in body condition during the transition period, serum metabolites pre- and postpartum, and postpartum milk yield and milk composition in both primiparous and multiparous cows. We hypothesized that peripartum serum concentrations of insulin, glucose, NEFA, and BHB would be associated with prepartum BCS $\left(\mathbf{B C S}_{\mathrm{ap}}\right)$ and its variation during the transition period $(\boldsymbol{B} \mathbf{B C S})$, and that these variables would differ between primiparous and multiparous cows.

\section{MATERIALS AND METHODS}

\section{Animals and Study Design}

The study was performed on a Thuringian dairy farm with an average of $956 \pm 78$ lactating German Holstein cows between January 2016 and February
2017. Collection of biological specimens and the clinical examinations were performed within the framework of the cattle health monitoring program of the Thuringian Animal Health Service, in which cows of the herds under contract are monitored and counseled according to agreement. Every effort was made to minimize suffering during the sampling of blood and urine. The competent authority for research ethics approval granted a formal waiver of ethics approval.

The cows were kept in groups in freestall barns and fed a TMR ad libitum calculated separately for fresh, lactating, dry, and close-up cows. The main components were corn, grass silage, grains (barley, corn), and rape grist (Supplemental Table S1; https://doi.org/10.3168/ jds.2018-15762). The TMR was provided fresh twice a day, with the remaining feed moved into position at least 3 times in between. Close-up and calving cows were kept in groups of 2 to 4 on straw bedding (deep litter-loose housing). A separate group for fresh cows included cows from 2 to 10 DIM, with an average group size of $10(7-14)$ and a stocking density of $<1$ cows/ stall. Lactating cows were housed in pens for 50-100 cows, with individual open-ended cubicles, rubber mats as bedding, and slatted floors in the alleyways. Water was always freely available in self-filling troughs. The farm had an average daily milk yield of $33.3 \pm 1.3 \mathrm{~kg} /$ cow per day, with $4.3 \pm 0.2 \%$ fat and $3.5 \pm 0.1 \%$ protein. Given the considerable differences in expected values for variance in the metabolic variables, we did not calculate a specific sample size but allocated as many calving cows to the study as possible during the limited study period. Cows with fever or severe lameness at the initial clinical examination were not enrolled. A total of 607 cows of varying parity were included in the study. Cows that left the herd before $20 \mathrm{~d}$ postpartum because of death or premature culling were excluded from the statistical analysis (Table 1). The cows were first examined before calving while they were housed in the calving pens, and again after parturition, when 2 additional examinations were undertaken while the animals were being kept in fresh cow groups. Lactating cows were milked twice daily in a rotating milking parlor.

\section{Determination of BCS, Sampling Protocol, and Biochemical Analyses}

The animals were sampled and BCS was determined by the same veterinarian at 3 time points during the transition period: 10 to $1 \mathrm{~d}$ prepartum (ap), 2 to $4 \mathrm{~d}$ postpartum (pp1), and 12 to $20 \mathrm{~d}$ postpartum (pp2). Body condition score was recorded according to the method of Edmonson et al. (1989), and BCS variation from ap to pp2 was calculated. Blood samples were 
taken at each time point, and milk samples were taken after parturition to evaluate udder health. Blood was collected from coccygeal vessels into vacuum serum tubes (Vacutainer, Becton Dickinson GmbH, Heidelberg, Germany) 3 to $6 \mathrm{~h}$ after the first feed in the morning (sampling time: 0900 to $1300 \mathrm{~h}$ ). Samples were left at room temperature for clotting, and within 60 min the serum was separated by centrifugation $(4,800$ $\times g$ for $30 \mathrm{~min}$ ), divided into aliquots, and stored at $-20^{\circ} \mathrm{C}$ until the laboratory analysis.

Serum samples were analyzed in the laboratory of the Thuringian Animal Health Service (Jena, Germany) for NEFA, BHB, and glucose concentrations by automated spectrophotometry (Beckman Coulter Unicel DxC 600) using the following test kits: Wako Chemicals $\mathrm{GmbH}$ (Neuss, Germany) for NEFA; Randox Laboratories Ltd. (Crumlin, UK) for BHB; and proprietary methods (Beckman Coulter GmbH, Krefeld, Germany) for glucose. A commercially available radioimmunoassay (BioSource Europe S.A., Nivelles, Belgium) described elsewhere (Gottschalk et al., 2011) and modified for bovine serum was used to determine serum insulin concentrations. This assay was performed in the radioisotope laboratory of the Institute of Physiological Chemistry, Faculty of Veterinary Medicine, University of Leipzig, Germany.

\section{Test Day Data}

Milk yield data were retrieved from the database of the herd management software. Milk volumes were constantly recorded with an electronic milk meter in the milking system. The plausibility limit was set as in the official milk performance test (i.e., all milking events of the day with a total amount of milk $>2 \mathrm{~kg}$ were registered).

Fat and protein content were measured at the first official milk performance test using a high-capacity, fully automatic milk analyzer based on Fourier transform infrared analysis (Milkoscan 7 RM; Foss, Hillerød, Denmark) in the accredited laboratory of the regional dairy herd improvement organization. The fat-protein ratio (FPR) was calculated from fat and protein contents. The first test day varied from 7 to 49 DIM, with an average of 30 DIM. The results of the milk recording were discarded if the first test day was after 50 DIM.

\section{Statistical Analysis}

Relationships between $\mathrm{BCS}_{\mathrm{ap}}$ and $\triangle \mathrm{BCS}$ were represented with cross tables. Somers' D was used for quantifying the dependency of $\triangle \mathrm{BCS}$ on $\mathrm{BCS}_{\mathrm{ap}}$, because this value is suitable for ordinal values and considers dependencies.

Because the distribution of most of the variables (both original values and residuals) deviated noticeably from a normal distribution, we applied a logarithmic transformation to achieve similarity to a normal distribution. The absolute skewness value of the logarithmic values did not exceed 1 , and that of kurtosis did not exceed 2.3. We also plotted the frequency distribution of the residuals and compared it with the normal distribution, and this was also estimated to be almost normal. For presentation, the least squares mean and the limits of the $95 \%$ confidence interval were transformed back $\left(\mathrm{e}^{\mathrm{x}}\right)$, leading to asymmetric confidence intervals. Based on their prepartum BCS, cows were classified as intermediate $\left(\mathrm{BCS}_{\mathrm{ap}}=3.5\right.$ to 3.75$)$, obese $\left(\mathrm{BCS}_{\mathrm{ap}}\right.$

Table 1. Frequencies of $\mathrm{BCS}_{\mathrm{ap}}$ versus $\triangle \mathrm{BCS}$ for primiparous and multiparous cows ${ }^{1}$

\begin{tabular}{|c|c|c|c|c|c|}
\hline \multirow[b]{3}{*}{ Cows } & \multirow[b]{3}{*}{$\mathrm{BCS}_{\mathrm{ap}}$} & \multicolumn{4}{|c|}{ Number of cows } \\
\hline & & \multirow{2}{*}{$\begin{array}{l}\text { Recruited } \\
\text { for the } \\
\text { study }\end{array}$} & \multirow{2}{*}{$\begin{array}{l}\text { ap values } \\
\text { excluded }^{2}\end{array}$} & \multicolumn{2}{|c|}{ All values excluded ${ }^{3}$} \\
\hline & & & & Trauma & Other reasons \\
\hline \multirow[t]{4}{*}{ Primiparous cows } & $\leq 3.25$ & 40 & 7 & 1 & 0 \\
\hline & $3.50-3.75$ & 241 & 30 & 1 & 1 \\
\hline & $>4.00$ & 81 & 9 & 0 & 0 \\
\hline & $\bar{T}$ Total & 362 & 46 & 2 & 1 \\
\hline \multirow[t]{4}{*}{ Multiparous cows } & $\leq 3.25$ & 61 & 10 & 1 & 1 \\
\hline & $3.50-3.75$ & 128 & 10 & 0 & 4 \\
\hline & $\geq 4.00$ & 56 & 1 & 2 & 2 \\
\hline & $\bar{T}$ otal & 245 & 21 & 3 & 7 \\
\hline
\end{tabular}

${ }^{1} \triangle \mathrm{BCS}=$ calculated decrease of body condition within transit period (difference of BCS prepartum and BCS postpartum); $\mathrm{BCS}_{\mathrm{ap}}=$ assessed BCS prepartum.

${ }^{2}$ Antepartum (ap) values were excluded because of calving within $36 \mathrm{~h}$ after the prepartum examination.

${ }^{3}$ All values were excluded because the cow left the herd within the observation period. 
$\geq 4)$, or lean $\left(\mathrm{BCS}_{\mathrm{ap}} \leq 3.25\right)$. In the same way, we made an additional classification for changes in BCS: lowmobilizing cows had a $\triangle \mathrm{BCS} \leq 0.25$, high-mobilizing cows had a $\triangle \mathrm{BCS} \geq 0.75$, and intermediate-mobilizing cows had a $\triangle$ BCS between 0.25 and 0.75 .

We applied linear mixed models, taking into account repeated measurements under variable conditions based on generalized estimation equations (Liang and Zeger, 1986), to estimate the effects on the metabolic variables (serum concentrations of insulin, glucose, BHB, and NEFA) using SPSS 25 (procedure Genlin; IBM, Armonk, NY). We chose an unstructured working correlation matrix for repeated measurements on the subject cow. Thus, we estimated a separate correlation for each observation pair (ap-pp1, ap-pp2, pp1-pp2) using the following model (1):

$$
\begin{aligned}
\mathrm{y}_{\mathrm{ikl}}=\mu+ & \text { Lact }_{\mathrm{i}}+\mathrm{St}_{\mathrm{j}}+\mathrm{b}\left(\mathrm{St}_{\mathrm{j}}\right)+\mathrm{BCS} / \Delta \mathrm{BCS}_{\mathrm{k}} \\
& \times \text { Lact }_{\mathrm{i}} \times \mathrm{St}_{\mathrm{j}}+\mathrm{Sea}_{\mathrm{l}}+\mathrm{e}_{\mathrm{ijkl}},
\end{aligned}
$$

where $\mathrm{y}=$ phenotypic observations of the different characteristics; $\mu=$ total mean value; Lact $_{i}=$ fixed effect of the ith parity group (primiparous, multiparous); $\mathrm{St}_{\mathrm{j}}=$ fixed effect of the stage (ap, pp1, pp2); b(St $\left.\mathrm{j}_{\mathrm{j}}\right)$ $=$ fixed regression for day ap or pp within the stage; $\mathrm{BCS} / \Delta \mathrm{BCS}_{\mathrm{k}} \times$ Lact $_{\mathrm{i}} \times \mathrm{St}_{\mathrm{j}}=$ interaction of the BCS group/alternatively change in BCS $\times$ parity group $\times$ stage; Sea $_{1}=$ fixed effect of the season of data recording; and $\mathrm{e}_{\mathrm{ijk} \mathrm{l}}=$ random residual effect, unstructured correlating between the phases (ap, pp1, pp2) within cow. Robust estimates were used for the standard errors. These included the empirical variances of the residuals and estimated asymptotically correct standard errors, even where the residual distribution deviated from the assumed distribution (in this case, Gaussian distribution). Robust estimation is also suitable if homoscedasticity is not achieved, so that despite the slight deviation from the normal distribution and the clearly different variances between stages, confidence intervals may be estimated with sufficient accuracy.

To account for a bias by removing animals from the analysis, we used a multiple imputation in a second analysis. Because the results were very similar to that of the first analysis, we have not presented them.

For daily milk yield, we included the lactation curves according to Ali and Schaeffer (1987) in the model in the lactation group $\times$ BCS class (alternatively, BCS difference), allowing us to display the lactation curve for each of these groups (2):

$$
\begin{aligned}
& \mathrm{y}_{\mathrm{ikl}}=\mu+\text { Lact }_{\mathrm{i}}+\mathrm{BCS} / \Delta \mathrm{BCS}_{\mathrm{k}} \times \text { Lact }_{\mathrm{i}}+\text { Sea }_{\mathrm{l}} \\
& +\Sigma\left(b_{\mathrm{j}} \times \mathrm{z}_{\mathrm{j}}\right)\left(\text { BCS } / \Delta \mathrm{BCS}_{\mathrm{k}} \times \text { Lact }_{\mathrm{i}}\right)+\mathrm{e}_{\mathrm{ijk}} .
\end{aligned}
$$

Variable definitions were identical to [1], except that $b_{j}$ $=$ fixed regression of Ali-Schaeffer $(\mathrm{j}=1,2,3,4) ; \mathrm{z}_{\mathrm{j}}=$ functional terms $\left[\mathrm{z}_{1}=\mathrm{DIM} / 305, \mathrm{z}_{2}=\mathrm{z}_{1}^{2}, \mathrm{z}_{3}=\log (305 /\right.$ DIM), $\left.\mathrm{z}^{4}=\mathrm{z}_{3}{ }^{2}\right]$; and $\mathrm{e}_{\mathrm{ijk}}=$ random residual effect, with autoregressive correlation between consecutive DIM within cow.

Generalized linear models (McCullagh and Nelder, 1989) were applied to estimate effects on production traits from the official milk testing (fat and protein content as well as FPR). In this case, we also included polynomials 1 to 3 of DIM in the model as covariables. Here, a simplified model (3) was sufficient:

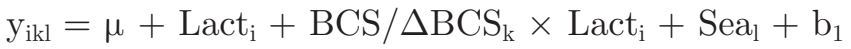

$$
\begin{aligned}
& \times \mathrm{DIM}+\mathrm{b}_{2} \times \mathrm{DIM}^{2}+\mathrm{b}_{3} \times \mathrm{DIM}^{3}+\mathrm{e}_{\mathrm{ikl}},
\end{aligned}
$$

in which the variables were the same as those defined in [1] but without correlation of residuals.

Based on the arguments of Moran (2003), a "familywise error rate" correction of the error probability was not used. To reduce false findings in multiple testing situations, we used the Benjamini-Hochberg procedure based on false discovery rate (Benjamini and Hochberg, 1995). The proportion of false findings to total findings Q was set at $5 \%$. We used this adjustment for the pairwise comparisons of interest, in this case each variable in the respective time point.

\section{RESULTS}

A total of 359 primiparous and 235 multiparous German Holstein cows were included in the analysis and classified according to $\mathrm{BCS}_{\mathrm{ap}}$ and $\triangle \mathrm{BCS}$ (Table 2 ). Of those, 67 cows calved within $36 \mathrm{~h}$ after the first examination, and prepartum metabolic variables were excluded (Table 1). During the study (i.e., before reaching pp2), 13 cows left the herd because of trauma or other reasons and were completely excluded from the analysis.

We found no association between $\mathrm{BCS}_{\mathrm{ap}}$ and $\triangle \mathrm{BCS}$ in multiparous cows (Somers' $\mathrm{D}=0.061, P>0.05$ for primiparous), but in primiparous cows, Somers' D for these variables was 0.296 and was significant $(P<$ $0.05)$.

\section{Metabolic Variables of Primiparous and Multiparous Cows}

As shown in Table 3, primiparous and multiparous cows differed markedly in mean prepartum and postpartum concentrations of insulin, NEFA, and BHB, but to a lesser extent in serum glucose concentrations. 
Table 2. Frequencies of $\mathrm{BCS}_{\mathrm{ap}}$ versus $\triangle \mathrm{BCS}$ for primiparous and multiparous cows ${ }^{1}$

\begin{tabular}{llrrrr}
\hline & & \multicolumn{3}{c}{$\Delta$ BCS } & \\
Cows $^{2}$ & BCS $_{\text {ap }}$ & $\leq 0.25$ & 0.50 & $\geq 0.75$ & \multirow{2}{*}{ Total } \\
\hline Primiparous cows & $\leq 3.25$ & 20 & 16 & 3 & 39 \\
& $3.50-3.75$ & 89 & 97 & 53 & 239 \\
& $\geq 4.00$ & 15 & 27 & 39 & 81 \\
Multiparous cows & Total & 124 & 140 & 95 & 359 \\
& & & & & \\
& $\leq 3.25$ & 19 & 25 & 15 & 59 \\
& $3.50-3.75$ & 11 & 55 & 32 & 124 \\
& $\geq 4.00$ & 67 & 106 & 62 & 235 \\
\hline
\end{tabular}

${ }^{1} \triangle \mathrm{BCS}=$ calculated decrease of body condition within transit period (difference of BCS prepartum and BCS postpartum); $\mathrm{BCS}_{\mathrm{ap}}=$ assessed BCS prepartum.

${ }^{2}$ If the BCS decrease was dependent on $\mathrm{BCS}_{\mathrm{ap}}$, the value of Somers' D was $0.296(P<0.05)$ for primiparous cows and $0.061(P>0.05)$ for multiparous cows.

Compared with multiparous cows, serum insulin concentrations in primiparous cows were lower prepartum but higher postpartum. As well, serum NEFA concentrations of primiparous cows were higher prepartum and lower postpartum than those of multiparous cows. Irrespective of parity, the highest NEFA concentrations were measured at pp1. Serum glucose concentrations of multiparous cows were lower and serum BHB concentrations were higher at each stage of the transition period compared with primiparous cows. Multiparous cows had decreasing glucose concentrations from prepartum to $\mathrm{pp} 2$.

\section{Associations Between Prepartum BCS and Metabolic Variables or Milk Yield}

Associations between metabolic variables and $\mathrm{BCS}_{\text {ap }}$ in primiparous and multiparous cows are given in Figure 1 and Supplemental Table S2 (https://doi .org/10.3168/jds.2018-15762). Before calving, we identified a positive association between $\mathrm{BCS}_{\mathrm{ap}}$ class and serum insulin concentration in primiparous cows but not in multiparous cows. We found no differences in serum glucose concentration among BCS classes at any time point for primiparous cows. Prepartum obese multiparous cows showed the highest serum glucose concentrations at $\mathrm{pp} 1$ and the lowest at $\mathrm{pp} 2$ compared with other multiparous cows. Prepartum and postpartum NEFA concentrations were positively associated with $\mathrm{BCS}_{\mathrm{ap}}$ class in multiparous cows, but not in primiparous cows. The $\mathrm{BCS}_{\mathrm{ap}}$ class showed no relationship to $\mathrm{BHB}$ serum concentration before or after calving in primiparous cows. With increasing BC$\mathrm{S}_{\mathrm{ap}}$ class in multiparous cows, we observed decreasing serum BHB concentrations prepartum and increasing concentrations at pp2.

Table 3. Glucose metabolism and fat mobilization in primiparous and multiparous cows at different sampling times ${ }^{1}$

\begin{tabular}{|c|c|c|c|c|c|}
\hline \multirow[b]{2}{*}{ Variable } & \multirow[b]{2}{*}{ Sampling time } & \multicolumn{2}{|c|}{ Primiparous cows } & \multicolumn{2}{|c|}{ Multiparous cows } \\
\hline & & LSM & $95 \% \mathrm{CI}$ & LSM & $95 \% \mathrm{CI}$ \\
\hline \multirow{2}{*}{$\operatorname{Insulin}^{2}(\mathrm{nmol} / \mathrm{L})$} & Postpartum 1 & $0.060^{\mathrm{d}}$ & $0.057-0.062$ & $0.044^{\mathrm{b}}$ & $0.042-0.046$ \\
\hline & Postpartum 2 & $0.050^{\mathrm{c}}$ & $0.047-0.052$ & $0.039^{\mathrm{a}}$ & $0.038-0.041$ \\
\hline \multirow{2}{*}{ Glucose (mmol/L) } & Antepartum & $4.298^{\mathrm{d}}$ & $4.256-4.339$ & $3.920^{\mathrm{c}}$ & $3.866-3.975$ \\
\hline & Postpartum 1 & $4.402^{\mathrm{e}}$ & $4.349-4.455$ & $3.636^{\mathrm{b}}$ & $3.561-3.710$ \\
\hline \multirow{2}{*}{ Nonesterified fatty $\operatorname{acids}^{2}(\mathrm{mmol} / \mathrm{L})$} & Postpartum 1 & $0.669^{\mathrm{e}}$ & $0.644-0.694$ & $0.692^{\mathrm{e}}$ & $0.653-0.734$ \\
\hline & Postpartum 2 & $0.395^{\mathrm{c}}$ & $0.379-0.412$ & $0.541^{\mathrm{d}}$ & $0.510-0.575$ \\
\hline \multirow{3}{*}{$\mathrm{BHB}^{2}(\mathrm{mmol} / \mathrm{L})$} & Antepartum & $0.571^{\mathrm{a}}$ & $0.559-0.583$ & $0.746^{\mathrm{c}}$ & $0.718-0.776$ \\
\hline & Postpartum 1 & $0.654^{\mathrm{b}}$ & $0.633-0.675$ & $0.831^{\mathrm{d}}$ & $0.797-0.867$ \\
\hline & Postpartum 2 & $0.658^{\mathrm{b}}$ & $0.632-0.685$ & $0.977^{\mathrm{e}}$ & $0.913-1.045$ \\
\hline
\end{tabular}

\footnotetext{
${ }^{\mathrm{a}-\mathrm{f}}$ Values with different superscript letters represent significant differences between parity group $\times$ sampling time $(P<0.05)$.

${ }^{1}$ Antepartum (10 to $1 \mathrm{~d}$ prepartum); postpartum 1 ( 2 to $4 \mathrm{~d}$ postpartum); postpartum 2 (12 to $20 \mathrm{~d}$ postpartum).

${ }^{2}$ Statistical analysis with logarithmic values $[\ln (\mathrm{x})]$; for presentation, the results are potentiated $\left(\mathrm{e}^{\mathrm{x}}\right)$.
} 
Milk yield was not associated with $\mathrm{BCS}_{\mathrm{ap}}$ class in primiparous cows, but in multiparous cows we observed a decrease in milk yield in obese cows compared with lean and intermediate multiparous cows during early lactation (Figure 2). Milk fat percentage at the first test day was higher in prepartum obese cows, irrespective of parity. Obese multiparous prepartum cows had a lower milk protein percentage at first test day. A positive association between $\mathrm{BCS}_{\text {ap }}$ class and FPR was observed in multiparous cows and, to a lesser extent, in primiparous cows (Table 4).

\section{Associations Between Difference in BCS and Metabolic Variables or Milk Yield}

We did not find an association between $\triangle \mathrm{BCS}$ class and prepartum serum insulin concentration in primiparous cows (Figure 3, Supplemental Table S3; https:/ primiparous prepartum
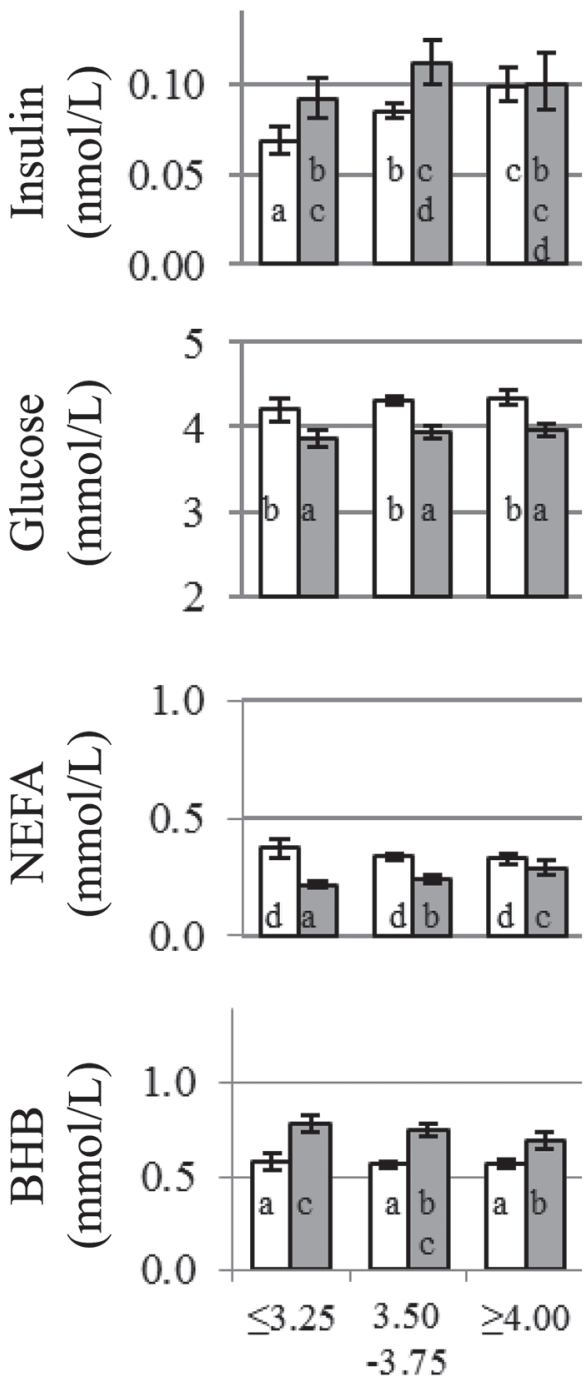
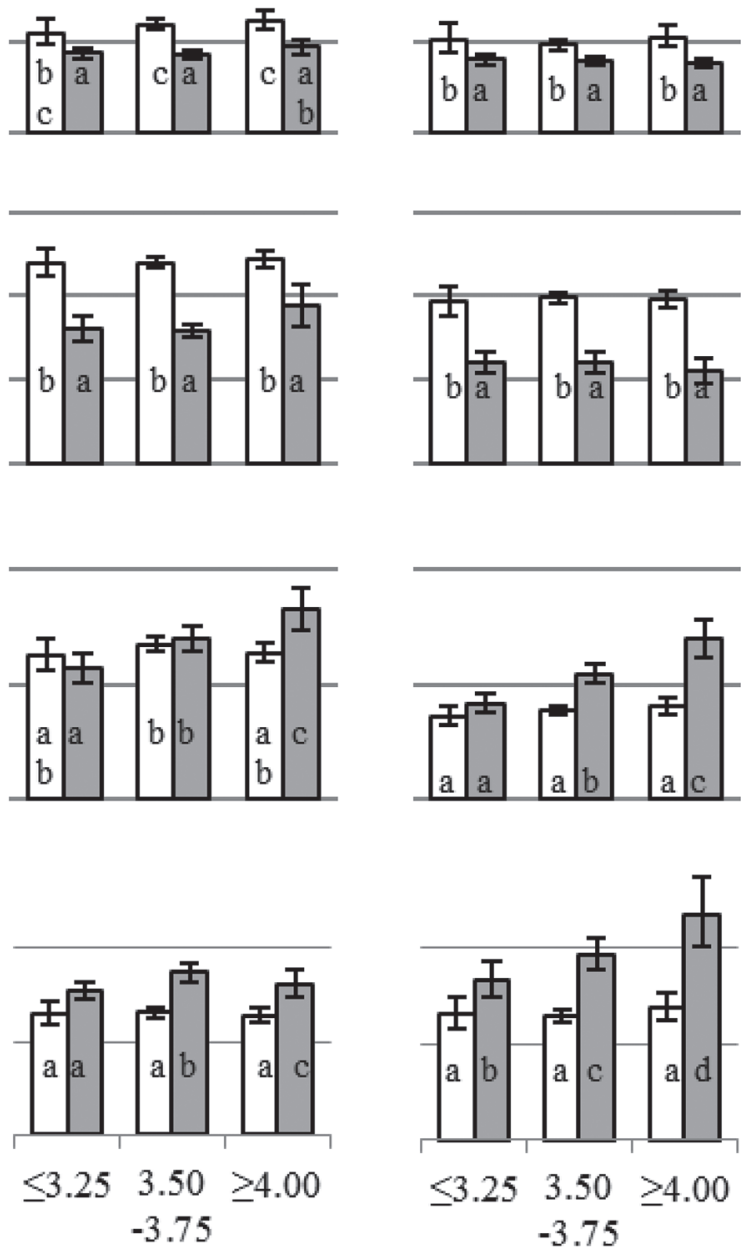

\section{BCS antepartum}

Figure 1. Least squares means and 95\% CI for glucose metabolism and fat mobilization by antepartum (ap) BCS class in primiparous (white bars) and multiparous (gray bars) cows at 10 to $1 \mathrm{~d}$ prepartum, 2 to $4 \mathrm{~d}$ postpartum (postpartum 1) and 12 to $20 \mathrm{~d}$ postpartum (postpartum 2). Different letters $(\mathrm{a}-\mathrm{d})$ represent significant differences between parity group $\times$ BCS class $(P<0.05)$. NEFA $=$ nonesterified fatty acids. 


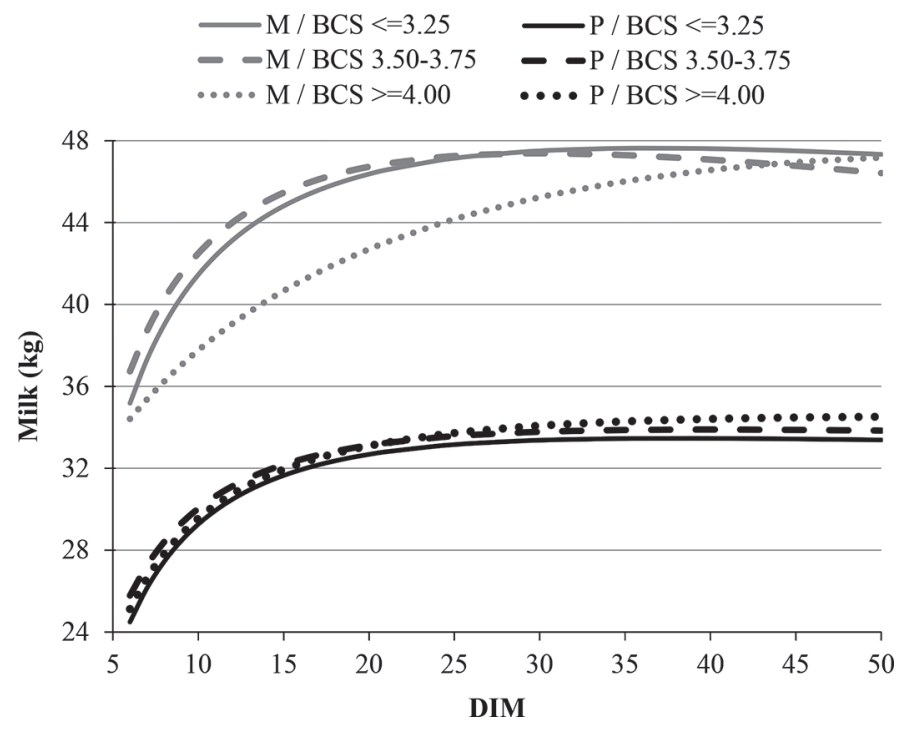

Figure 2. Lactation curves (milk yield) for different BCS classes by parity group (gray lines, multiparous cows, M; black lines, primiparous cows, P; solid lines, BCS $\leq 3.25$; dashed lines, BCS 3.5-3.75; dotted lines, BCS $\geq 4.00)$. Differences between parity groups were significant at $10,20,30,40$, and 50 DIM. Multiparous cows with BCS $\geq 4.0$ differed from the 2 other classes at DIM 10 and 20. We found no significant differences in primiparous cows.

/doi.org/10.3168/jds.2018-15762). After calving, lowmobilizing primiparous cows had the highest insulin concentrations. We observed a negative relationship between $\triangle \mathrm{BCS}$ class and serum insulin concentration prepartum but not postpartum in multiparous cows. Furthermore, $\triangle B C S$ class was not related to serum glucose concentrations in either primiparous or multiparous cows. Serum NEFA concentrations were positively associated with $\triangle \mathrm{BCS}$ class in multiparous cows at each stage of the transition period. In primiparous cows, we observed this association only at $\mathrm{pp} 2$ to a lesser degree, but not at the prepartum stage or at pp1. Similarly, serum BHB concentrations were not related to $\triangle \mathrm{BCS}$ class in primiparous cows at any time, but in multiparous cows these variables were associated only at pp1.

We found no clear relationship between $\triangle \mathrm{BCS}$ classes and milk yield in primiparous cows (Figure 4). In contrast, milk yield of high-mobilizing multiparous cows was lower than that of the 2 other groups of multiparous cows at the start of lactation. At the same time, these cows had the highest fat percentage and, as a result, the highest FPR. Milk protein percentage was not affected by $\triangle \mathrm{BCS}$ class in multiparous cows, but we did observe a negative association in primiparous cows (Table 5).

\section{DISCUSSION}

The present study was performed in a commercial dairy herd, monitoring cows in the production process and involving a substantial proportion of primiparous cows. To our knowledge, little is known about the peripartal metabolic status and interrelationships with body condition, body condition loss and milk yield in primiparous cows compared with their multiparous herd mates. Focusing on markers of energy balance and lipid metabolism (e.g., serum concentrations of NEFA, BHB, glucose, and insulin), several previous studies have pointed out a parity effect (Meikle et al., 2004; Wathes et al., 2007). Wathes et al. (2007) presented higher serum concentrations of insulin in primiparous cows during the entire transition period, although they found no significant differences compared with the multiparous cows. In contrast, Meikle et al. (2004) measured higher insulin concentrations in multiparous compared with primiparous cows, but the effect of parity was not significant. Both studies found different postpartum NEFA concentrations in primiparous and multiparous cows, but their results were contrasting. Ruprechter et al. (2018) described an influence of parity on peripartal

Table 4. Milk content depending on prepartum BCS class

\begin{tabular}{|c|c|c|c|c|c|}
\hline \multirow{2}{*}{$\begin{array}{l}\text { Milk content, } \\
\text { first test day }\end{array}$} & \multirow[b]{2}{*}{ BCS } & \multicolumn{2}{|c|}{ Primiparous cows } & \multicolumn{2}{|c|}{ Multiparous cows } \\
\hline & & LSM & $95 \% \mathrm{CI}$ & LSM & $95 \% \mathrm{CI}$ \\
\hline \multirow[t]{3}{*}{ Fat $(\%)$} & $\leq 3.25$ & $3.92^{\mathrm{a}}$ & $3.71-4.14$ & $4.32^{\mathrm{bc}}$ & $4.14-4.50$ \\
\hline & $3.50-3.75$ & $4.20^{\mathrm{b}}$ & $4.11-4.28$ & $4.54^{\mathrm{c}}$ & $4.41-4.66$ \\
\hline & $\geq 4.00$ & $4.32^{\mathrm{b}}$ & $4.17-4.47$ & $5.03^{\mathrm{d}}$ & $4.85-5.22$ \\
\hline \multirow[t]{3}{*}{ Protein $(\%)$} & $\leq 3.25$ & $3.23^{\mathrm{b}}$ & $3.16-3.30$ & $3.23^{\mathrm{b}}$ & $3.17-3.29$ \\
\hline & $\overline{3.50-3.75}$ & $3.22^{\mathrm{b}}$ & $3.19-3.25$ & $3.18^{\mathrm{b}}$ & $3.14-3.22$ \\
\hline & $\geq 4.00$ & $3.23^{\mathrm{b}}$ & $3.18-3.28$ & $3.08^{\mathrm{a}}$ & $3.02-3.15$ \\
\hline \multirow[t]{3}{*}{ Fat-protein ratio } & $\leq 3.25$ & $1.22^{\mathrm{a}}$ & $1.15-1.30$ & $1.35^{\mathrm{b}}$ & $1.29-1.41$ \\
\hline & $\overline{3.50-3.75}$ & $1.31^{\mathrm{b}}$ & $1.28-1.34$ & $1.43^{\mathrm{c}}$ & $1.39-1.47$ \\
\hline & $\geq 4.00$ & $1.34^{\mathrm{b}}$ & $1.29-1.40$ & $1.64^{\mathrm{d}}$ & $1.57-1.70$ \\
\hline
\end{tabular}

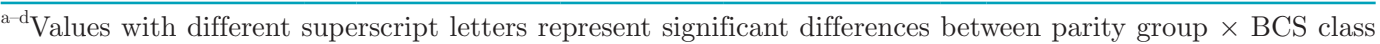
$(P<0.05)$. 
serum NEFA and BHB concentrations depending on diseases early postpartum, so these results were not comparable with those of our study.

Performing this study in only one herd and over approximately 1 yr enhances its internal validity. Because all primiparous and multiparous cows are exposed to these influences in the same way and extent, this controls for herd-level factors such as management, feeding, quality of feedstuff, and seasonal and climate effects. Furthermore, all cows were pure-bred German Holstein dairy cows. This genetic uniformity limited the influence of genetic background on low insulin sensitivity as detected by Chagas et al. (2009) between Holstein-Friesian dairy cows from North America or New Zealand and by Pieper et al. (2016) among German Holstein-Friesian bulls. We are aware that several

\section{口primiparous $\quad \square$ multiparous}

\section{prepartum postpartum $1 \quad$ postpartum 2}
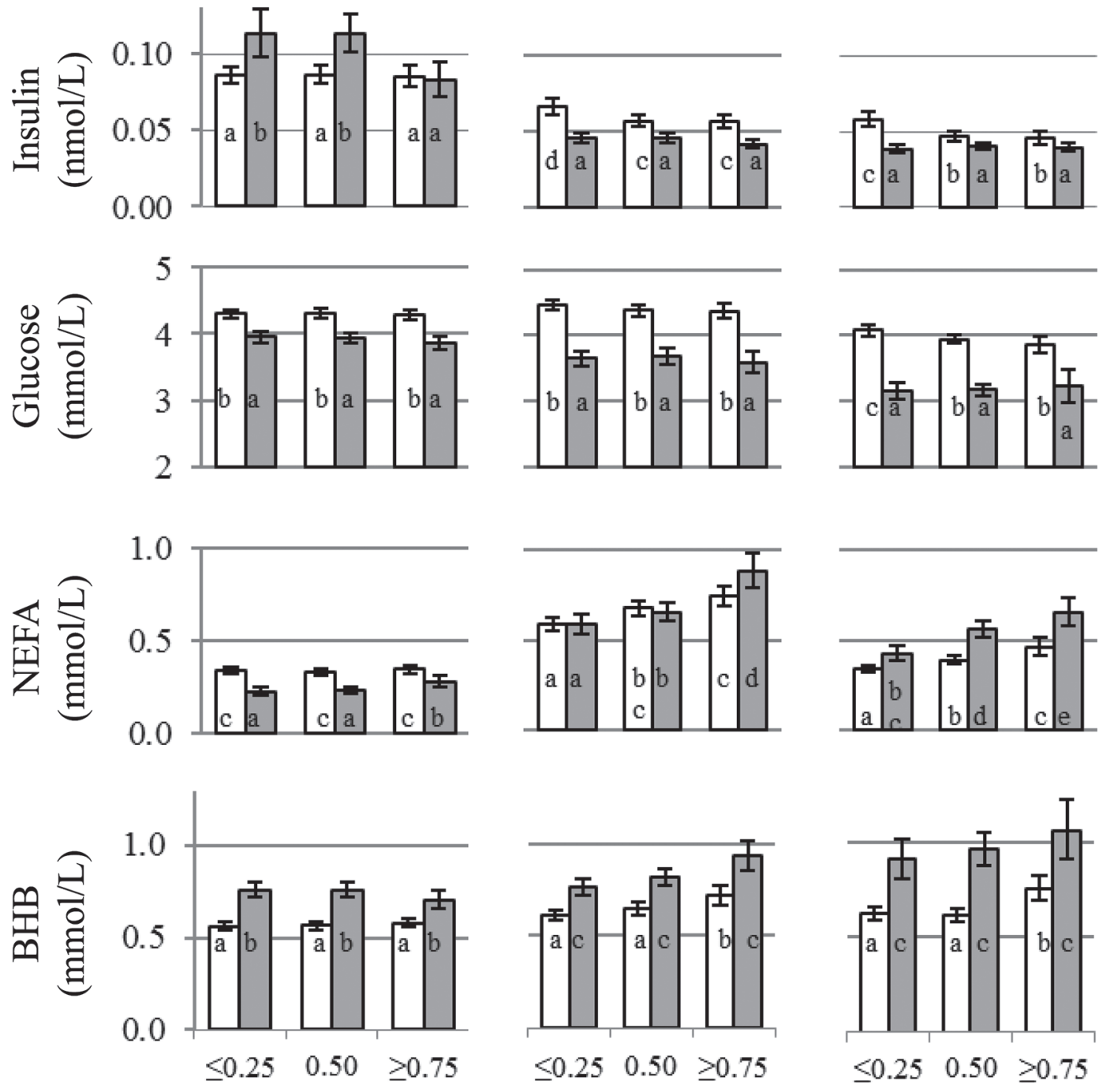

\section{BCS decrease}

Figure 3. Least squares means and $95 \%$ CI for glucose metabolism and fat mobilization by BCS decrease during the transition period (from 10 to $1 \mathrm{~d}$ prepartum to 12 to $20 \mathrm{~d}$ postpartum) in primiparous (white bars) and multiparous (gray bars) cows at 10 to $1 \mathrm{~d}$ prepartum, 2 to $4 \mathrm{~d}$ postpartum (postpartum 1), and 12 to $20 \mathrm{~d}$ postpartum (postpartum 2). Different letters represent significant differences between parity group $\times$ BCS decrease class $(P<0.05)$. NEFA $=$ nonesterified fatty acids. 
Table 5. Milk content depending on BCS decrease $(\triangle \mathrm{BCS})$ during the transition period ${ }^{1}$

\begin{tabular}{|c|c|c|c|c|c|}
\hline \multirow{2}{*}{$\begin{array}{l}\text { Milk content, } \\
\text { first test day }\end{array}$} & \multirow[b]{2}{*}{$\triangle \mathrm{BCS}$} & \multicolumn{2}{|c|}{ Primiparous cows } & \multicolumn{2}{|c|}{ Multiparous cows } \\
\hline & & LSM & $95 \% \mathrm{CI}$ & LSM & $95 \% \mathrm{CI}$ \\
\hline \multirow[t]{3}{*}{ Fat $(\%)$} & $\leq 0.25$ & $4.20^{\mathrm{ab}}$ & $4.07-4.32$ & $4.43^{\mathrm{cd}}$ & $4.26-4.60$ \\
\hline & 0.50 & $4.09^{\mathrm{a}}$ & $3.97-4.21$ & $4.58^{\mathrm{de}}$ & $4.45-4.71$ \\
\hline & $\geq 0.75$ & $4.34^{\mathrm{bc}}$ & $4.20-4.48$ & $4.79^{\mathrm{e}}$ & $4.61-4.97$ \\
\hline \multirow[t]{3}{*}{ Protein $(\%)$} & $\leq 0.25$ & $3.30^{\mathrm{c}}$ & $3.26-3.34$ & $3.21^{\mathrm{b}}$ & $3.15-3.26$ \\
\hline & 0.50 & $3.22^{\mathrm{b}}$ & $3.18-3.26$ & $3.15^{\mathrm{ab}}$ & $3.10-3.19$ \\
\hline & $\geq 0.75$ & $3.13^{\mathrm{a}}$ & $3.08-3.17$ & $3.17^{\mathrm{ab}}$ & $3.11-3.23$ \\
\hline \multirow[t]{3}{*}{ Fat-protein ratio } & $\leq 0.25$ & $1.28^{\mathrm{a}}$ & $1.24-1.32$ & $1.39^{\mathrm{b}}$ & $1.33-1.44$ \\
\hline & $\overline{0} .50$ & $1.27^{\mathrm{a}}$ & $1.23-1.31$ & $1.46^{\mathrm{bc}}$ & $1.42-1.51$ \\
\hline & $\geq 0.75$ & $1.40^{\mathrm{b}}$ & $1.35-1.45$ & $1.52^{\mathrm{c}}$ & $1.46-1.58$ \\
\hline
\end{tabular}

${ }^{\mathrm{a}-\mathrm{e}}$ Values with different superscript letters represent significant differences between parity group $\times \Delta \mathrm{BCS}$ class $(P<0.05)$.

${ }^{1}$ From 10 to $1 \mathrm{~d}$ prepartum to 12 to $20 \mathrm{~d}$ postpartum.

unknown factors specific to the study herd may diminish external validity. We accepted these limitations because the main objective was to compare primiparous and multiparous cows, and for this purpose internal validity was more important.

By measuring NEFA and BHB as the metabolic variables used most often in the metabolic monitoring of dairy cows (Ospina et al., 2013; Overton et al., 2017),

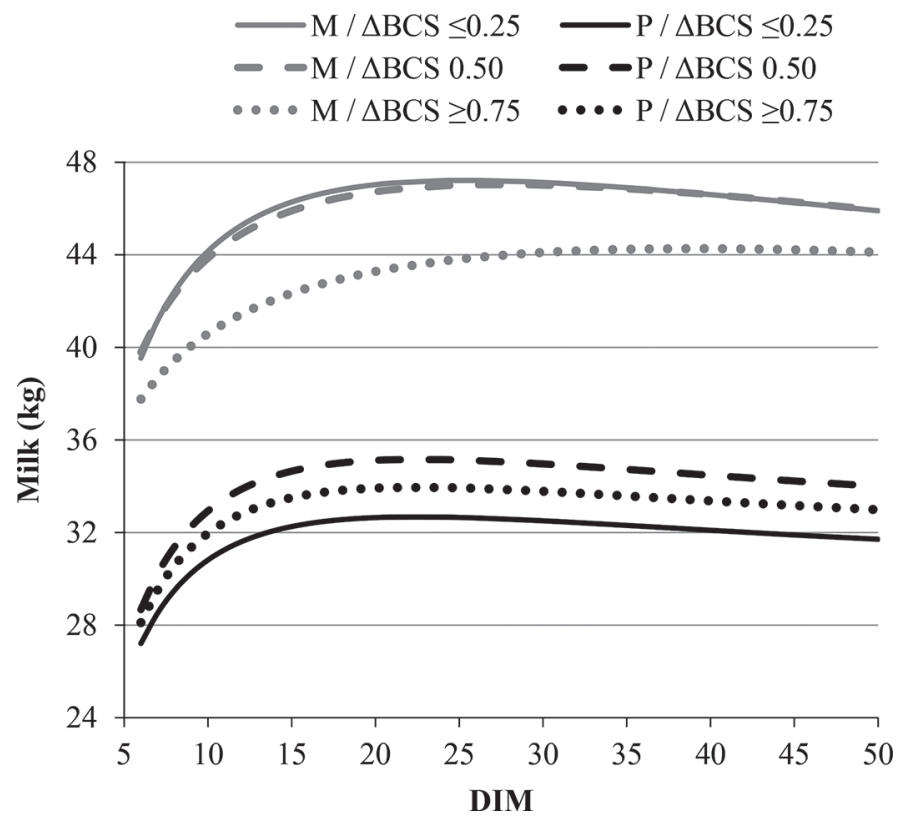

Figure 4. Lactation curves (milk yield) for different BCS decrease ( $\triangle \mathrm{BCS}$ ) classes by parity group (gray lines, multiparous cows, $\mathrm{M}$; black lines, primiparous cows, $\mathrm{P}$; continuous lines, $\triangle \mathrm{BCS} \leq 0.25$ dashed lines, $\triangle \mathrm{BCS} 0.5$; dotted lines, $\triangle \mathrm{BCS} \geq 0.75$ ). Differences between parity groups were significant at 10, 20, 30, 40, and 50 DIM. Primiparous cows with $\triangle \mathrm{BCS} \leq 0.25$ differed significantly from the $\triangle$ BCS 0.5 group at $10,20,30,40$, and 50 DIM. Multiparous cows with $\triangle \mathrm{BCS} \geq 0.75$ differed significantly from the 2 other classes at 10 and 20 DIM. we observed differences between primiparous and multiparous cows. In general, primiparous cows had higher prepartum and lower postpartum serum NEFA concentrations than their multiparous herd mates. This was in accordance with Wathes et al. (2007), but Meikle et al. (2004) found higher NEFA concentrations in primiparous cows postpartum. The most striking finding of our study was that obese primiparous cows in late pregnancy were not prone to accelerated postpartum lipolysis as is the case for multiparous cows. With respect to $\mathrm{BCS}_{\mathrm{ap}}$ class, we did not observe differences in postpartum serum NEFA concentrations in primiparous cows. In contrast, obese multiparous cows $\left(\mathrm{BCS}_{\mathrm{ap}} \geq 4.00\right)$ had higher serum NEFA concentrations prepartum and postpartum compared with their lean herd mates. This was in line with other studies that included only multiparous cows (Pires et al., 2013; Roche et al., 2015). Other authors found no association or even a negative association between prepartum BCS and peripartum serum NEFA concentrations, which could have been caused by a lower prepartum BCS as well as a pasture-based diet in these studies (Meikle et al., 2004; Wathes et al., 2007). We detected a positive association of body condition loss ( $\triangle \mathrm{BCS}$ class) with serum NEFA concentrations in multiparous cows before and after calving, and to a lesser extent and only at pp2 in primiparous cows.

In our study, high-mobilizing multiparous cows had higher serum BHB concentrations early postpartum (pp1), but obese multiparous cows were characterized by higher BHB concentrations 2 to 3 wk postpartum. This was consistent with the results of Roche et al. (2015) who showed a greater body condition loss in fatter cows, combined with higher serum BHB concentrations and higher milk yield. Contrary to the results of their study, in our study both the obese and the high-mobilizing multiparous cows showed a lower milk 
yield than their multiparous herd mates (Figures 2 and 4 ), whereas in primiparous cows we observed no associations between $\mathrm{BCS}_{\mathrm{ap}}$ or $\triangle \mathrm{BCS}$ class and serum $\mathrm{BHB}$ concentrations or milk yield.

We also detected differences in glucose and insulin concentrations with respect to parity. Generally, multiparous cows had lower prepartum and postpartum serum glucose concentrations than primiparous cows, but postpartum insulin concentrations were higher in primiparous cows (Table 3). Before calving, multiparous cows showed higher serum insulin concentrations than primiparous cows. This came with lower prepartum NEFA concentrations in multiparous cows compared with their primiparous herd mates, which could indicate a better prepartal energy balance in multiparous cows. Similarly, Wathes et al. (2007) found prepartum lower and postpartum higher serum NEFA concentrations in multiparous compared with primiparous cows, but in their results, primiparous cows always had slightly but not significantly higher insulin concentrations than multiparous cows. However, Meikle et al. (2004) found pre- and postpartum higher NEFA concentrations in primiparous compared with multiparous cows and no effect of parity on insulin concentration. Therefore, our findings underline that insulin is an important regulator of fat metabolism. In our study, irrespective of parity, $\mathrm{BCS}_{\mathrm{ap}}$, or $\triangle \mathrm{BCS}$ class, serum insulin concentrations decreased after calving, consistent with other studies (Holtenius et al., 2003; Meikle et al., 2004; Wathes et al., 2007; Pires et al., 2013). Primiparous cows showed postpartum higher glucose and insulin concentrations, as well as lower NEFA concentrations compared with multiparous cows, suggesting that energy demands for ongoing growth are preferred, because higher insulin concentrations can stimulate lipogenesis, the most relevant insulin response in adipose tissue (De Koster and Opsomer, 2013). Another study with multiparous cows also demonstrated the influence of parity, with higher postpartum insulin concentrations in cows at second calving than in cows with higher lactation numbers (Pires et al., 2013).

We found that $\mathrm{BCS}_{\mathrm{ap}}$ was positively associated with prepartum serum insulin concentrations in primiparous cows. This was in accordance with the results of another German study, which demonstrated higher back fat thickness and insulin serum concentrations before calving in intensively fed primiparous cows (Goerigk et al., 2011). Serum insulin concentration is positively correlated with energy intake and reflects a positive energy balance (Chilliard et al., 1998; Holtenius et al., 2003). Indeed, the obese heifers in our study showed the greatest feed intake, roughly estimated by recording of rumen fill (data not shown). As expected, our data showed a perceptible but nonsignificant negative association of $\mathrm{BCS}_{\mathrm{ap}}$ class with prepartum serum NEFA. In the previously mentioned German study, intensively fed primiparous cows had enhanced prepartum and postpartum fat mobilization (Goerigk et al., 2011). This corresponded with the association between fat accumulation $\left(\mathrm{BCS}_{\mathrm{ap}}\right)$ and mobilization $(\triangle \mathrm{BCS})$ in the primiparous cows of our study (Table 2). However, postpartum NEFA concentrations in primiparous cows showed no relation to $\mathrm{BCS}_{\mathrm{ap}}$ and a positive association with $\triangle$ BCS only at pp2.

In our study, high $\mathrm{BCS}_{\mathrm{ap}}$ class was associated with elevated NEFA concentrations in multiparous cows prepartum and postpartum, as well as with higher serum BHB concentrations in multiparous cows at pp2, suggesting that the overconditioned multiparous cows were predisposed to enhanced postpartum fat mobilization. In contrast to this, 2 other studies (Meikle et al., 2004; Wathes et al., 2007) reported a negative correlation of prepartum BCS with postpartum BHB concentration, which could be explained by a generally low $\mathrm{BCS}_{\mathrm{ap}}$ in these studies compared with ours. These different results suggest that poor body condition may lead to metabolic disorders similar to obesity. In a previous study, overconditioned cows had larger adipocytes and were predisposed to excessive fat mobilization; these large adipocytes showed higher lipolytic activity, but the antilipolytic effect of insulin was preserved in these cells (De Koster et al., 2016). In other studies, overweight cows had higher $\triangle \mathrm{BCS}$ during the transition period as well as higher postpartum NEFA concentrations (Roche et al., 2015), together with higher serum glucose and insulin concentrations (Rico et al., 2015). We observed a similar relationship in our cows. During the first days after calving (pp1), glucose and NEFA concentrations were both higher in prepartum obese multiparous cows. Furthermore, the reduced milk yield, reduced milk protein content, and enhanced milk fat content during early lactation reflect a lower energy status and may indicate a less successful adaptation to postpartum demands in prepartum obese multiparous cows.

Prepartum serum insulin concentrations were negatively associated with $\triangle \mathrm{BCS}$ class in multiparous cows, indicating that cows with the lowest prepartum serum insulin concentrations were those faced with the most intensive body condition loss. Because insulin serum concentration is positively correlated with energy intake (Chilliard et al., 1998), and presuming the same dietary energy density for all dry cows in the studied herd, we assumed a lower feed intake in the cows with low serum insulin concentrations before calving. As previously shown, serum insulin concentration regulates the phos- 
phorylation of the insulin receptor and its activity in adipose tissue, where differences with respect to body condition loss during the transition period have been identified (Zachut et al., 2013). In our study, prepartum obese cows had the most pronounced fat mobilization. Therefore, we hypothesize that prepartum low insulin secretion, which may be caused by low feed intake of obese cows or otherwise unknown regulators, predetermines low insulin serum concentration in the postpartum state, in which a decrease in pancreatic secretion is more relevant to insulin metabolism than different degrees of body fat mobilization (Weber et al., 2016).

The association between higher body condition loss $(\triangle \mathrm{BCS} \geq 0.75)$ and lower prepartum serum insulin concentrations in multiparous cows corresponds with higher prepartum and postpartum NEFA concentrations. Furthermore, these high-mobilizing multiparous cows were characterized by higher BHB concentrations at pp1, lower milk yield during the first 2 mo of lactation (Figure 4), and higher milk fat content and FPR compared with low-mobilizing cows (Table 5). With respect to $\triangle \mathrm{BCS}$ class, we detected no differences in serum glucose concentrations. This was in line with the results of previous studies that identified no effect of $\triangle \mathrm{BCS}$ class on the phosphorylation of the hepatic insulin receptor (Zachut et al., 2013) and gene expression for gluconeogenesis in the liver (Weber et al., 2017).

In primiparous cows, we observed fewer associations between metabolic variables and $\triangle \mathrm{BCS}$ class than in multiparous cows (Figure 3). We found no relationship with any of the metabolic variables measured in the prepartum stage. The only noticeable associations were found for low-mobilizing primiparous cows, which were characterized by high postpartum serum insulin concentrations, as well as higher serum glucose concentrations and lower NEFA concentrations at pp2. Obviously, these cows were prone to a hyperinsulinemic-hyperglycemic status. With respect to our results in general, it could be argued that this state is not a disorder in lipid metabolism as postulated by other authors (Han van der Kolk et al., 2017), but rather that it simply indicates a lower milk performance and probably also lower energy deficit in these cows. This explanation is supported by findings that NEFA concentrations in these cows were lower and milk protein content was higher compared with high-mobilizing primiparous cows. With respect to $\triangle \mathrm{BCS}$ class, we observed the lowest milk yield in the low-mobilizing primiparous cows (Figure 4), accompanied by low postpartum fat mobilization and higher insulin concentrations. Considering the antilipolytic effect of insulin, this suggests that in these cows higher insulin concentration limits the energy supply for milk production provided by $\beta$-oxidation of fatty acids. Presumably, these primiparous cows were characterized by low mobilization and low milk yield, as opposed to the cows of other $\triangle \mathrm{BCS}$ classes with higher mobilization and higher milk yield. Taking into consideration the fact that the primiparous cows were characterized by higher serum insulin concentrations accompanied by lower fat mobilization in general, the "high mobilization-high milk yield" state was found to be consistent with low insulin concentrations. This seems to be less advantageous for the homeostasis of energy and lipid metabolism. Similar to multiparous cows (Zachut et al., 2013), low insulin serum concentration may be associated with lower insulin receptor phosphorylation and activation in the adipose tissue, resulting in more pronounced lipolysis and leading to higher postpartum serum NEFA concentrations and greater loss in body condition.

We assume that some of the primiparous cows with a presumed higher pancreatic insulin secretion were more able to control lipolysis and body condition losses, keep serum glucose concentration high, and keep milk yield and milk fat content low. Further research is required to determine whether these differences are linked to genetic background, as previous studies suggest (Chagas et al., 2009; Pieper et al., 2016). The influence of heifers' BCS before first calving on metabolic balance should be proven carefully in future studies, in which the effects of obesity in primiparous cows on calving ease and resulting puerperal disorders should be taken into consideration.

\section{CONCLUSIONS}

Taken together, prepartum obese multiparous and high-mobilizing cows, irrespective of parity, were those who were less able to overcome metabolic challenges during the early postpartum period. They were characterized by high serum NEFA and BHB concentrations and lower milk yield, at least in multiparous cows. Low-mobilizing and primiparous cows, even if obese, had low serum NEFA and BHB concentrations. Higher postpartum serum insulin concentrations allow primiparous cows to prevent excessive postpartal lipolysis better than multiparous cows. This was associated with lower milk yield and was most pronounced in low-mobilizing primiparous cows, leading to the lowest milk yield in this group. Avoiding high body condition loss during the transition period is a main factor in preventing peripartal metabolic imbalances of glucose and fat metabolism.

\section{ACKNOWLEDGMENTS}

The authors are very grateful to Florian Schmidt, Nadine Bergk, Regina Rother, and the other staff of 
the dairy farm for their excellent assistance and support during the study. In addition, they are grateful to the staff at the laboratory of the Thuringian Animal Health Service (Jena, Germany) and the laboratory of the Institute of Physiological Chemistry (Leipzig, Germany) for biochemical analysis of the blood samples, and to Nicola Wilton for improving the English style. The work was financially supported by the European Agricultural Fund for Rural Development (EAFRD).

\section{REFERENCES}

Ali, T. E., and L. R. Schaeffer. 1987. Accounting for covariances among test day milk yields in dairy cows. Can. J. Anim. Sci. 67:637. https: //doi.org/10.4141/cjas87-067.

Bell, A. W. 1995. Regulation of organic nutrient metabolism during transition from late pregnancy to early lactation. J. Anim. Sci. $73: 2804-2819$.

Benjamini, Y., and Y. Hochberg. 1995. Controlling the false discovery rate: A practical and powerful approach to multiple testing. J. R. Stat. Soc. B 57:289-300.

Bossaert, P., J. L. M. R. Leroy, S. De Vliegher, and G. Opsomer. 2008 Interrelations between glucose-induced insulin response, metabolic indicators, and time of first ovulation in high-yielding dairy cows. J. Dairy Sci. 91:3363-3371. https://doi.org/10.3168/jds.2008-0994.

Chagas, L. M., M. C. Lucy, P. J. Back, D. Blache, J. M. Lee, P. J. Gore, A. J. Sheahan, and J. R. Roche. 2009. Insulin resistance in divergent strains of Holstein-Friesian dairy cows offered fresh pasture and increasing amounts of concentrate in early lactation. J. Dairy Sci. 92:216-222. https://doi.org/10.3168/jds.2008-1329.

Chilliard, Y., F. Bocquier, and M. Doreau. 1998. Digestive and metabolic adaptations of ruminants to undernutrition, and consequences on reproduction. Reprod. Nutr. Dev. 38:131-152.

De Koster, J, M. Hostens, M. van Eetvelde, K. Hermans, S. Moerman, H. Bogaert, E. Depreester, W. van den Broeck, and G. Opsomer. 2015. Insulin response of the glucose and fatty acid metabolism in dry dairy cows across a range of body condition scores. J. Dairy Sci. 98:4580-4592. https://doi.org/10.3168/jds.2015-9341.

De Koster, J., W. van den Broeck, L. Hulpio, E. Claeys, M. van Eetvelde, K. Hermans, M. Hostens, V. Fievez, and G. Opsomer. 2016. Influence of adipocyte size and adipose depot on the in vitro lipolytic activity and insulin sensitivity of adipose tissue in dairy cows at the end of the dry period. J. Dairy Sci. 99:2319-2328. https:// doi.org/10.3168/jds.2015-10440.

De Koster, J. D., and G. Opsomer. 2013. Insulin resistance in dairy cows. Vet. Clin. North Am. Food Anim. Pract. 29:299-322. https: //doi.org/10.1016/j.cvfa.2013.04.002.

Edmonson, A. J., I. J. Lean, L. D. Weaver, T. Farver, and G. Webster 1989. A body condition scoring chart for Holstein dairy cows. J. Dairy Sci. 72:68-78.

Goerigk, D., I. Steinhöfel, and M. Fürll. 2011. [Peripartaler "Revised Quantitative Insulin Sensitivity Check Index" (RQUICKI) bei unterschiedlich aufgezogenen Färsen.] Wien. Tierärztl. Mschr. 98:7681. [In German]

Goerigk, D., I. Steinhöfel, J. Gottschalk, and M. Fürll. 2010. [Energieund Fettstoffwechsel bei Färsen unterschiedlicher Aufzuchtintensitäten]. Tierarztl. Prax. 38:339-347. [In German]

Gottschalk, J., A. Einspanier, F. R. Ungemach, and G. Abraham. 2011. Influence of topical dexamethasone applications on insulin, glucose, thyroid hormone and cortisol levels in dogs. Res. Vet. Sci. 90:491-497.

Holtenius, K., S. Agenäs, C. Delavaud, and Y. Chilliard. 2003. Effects of feeding intensity during the dry period. 2. Metabolic and hormonal responses. J. Dairy Sci. 86:883-891. https://doi.org/10 .3168/jds.S0022-0302(03)73671-6.

Ji, P., J. S. Osorio, J. K. Drackley, and J. J. Loor. 2012. Overfeeding a moderate energy diet prepartum does not impair bovine sub- cutaneous adipose tissue insulin signal transduction and induces marked changes in peripartal gene network expression. J. Dairy Sci. 95:4333-4351. https://doi.org/10.3168/jds.2011-5079.

Liang, K., and S. L. Zeger. 1986. Longitudinal data analysis using generalized linear models. Biometrika 73:13-22. https://doi.org/ 10.1093/biomet/73.1.13.

Mann, S., D. V. Nydam, A. Abuelo, F. A. Leal Yepes, T. R. Overton, and J. J. Wakshlag. 2016. Insulin signaling, inflammation, and lipolysis in subcutaneous adipose tissue of transition dairy cows either overfed energy during the prepartum period or fed a controlled-energy diet. J. Dairy Sci. 99:6737-6752. https://doi.org/10 $.3168 /$ jds.2016-10969.

McCullagh, P., and J. A. Nelder. 1989. Generalized Linear Models. 2nd ed. Chapman and Hall, London, UK.

Meikle, A., M. Kulcsar, Y. Chilliard, H. Febel, C. Delavaud, D. Cavestany, and P. Chilibroste. 2004. Effects of parity and body condition at parturition on endocrine and reproductive parameters of the cow. Reproduction 127:727-737. https://doi.org/10.1530/rep .1 .00080

Moran, M. D. 2003. Arguments for rejecting the sequential Bonferroni in ecological studies. Oikos 100:403-405. https://doi.org/10.1034/ j.1600-0706.2003.12010.x.

Ospina, P. A., J. A. McArt, T. R. Overton, T. Stokol, and D. V. Nydam. 2013. Using nonesterified fatty acids and $\beta$-hydroxybutyrate concentrations during the transition period for herd-level monitoring of increased risk of disease and decreased reproductive and milking performance. Vet. Clin. North Am. Food Anim. Pract. 29:387-412. https://doi.org/10.1016/j.cvfa.2013.04.003.

Overton, T. R., J. A. McArt, and D. V. Nydam. 2017. A 100-year review: Metabolic health indicators and management of dairy cattle. J. Dairy Sci. 100:10398-10417. https://doi.org/10.3168/jds.2017 -13054 .

Pieper, L., R. Staufenbiel, J. Christ, L. Panicke, U. Müller, and G. A. Brockmann. 2016. Heritability of metabolic response to the intravenous glucose tolerance test in German Holstein Friesian bulls. J. Dairy Sci. 99:7240-7246. https://doi.org/10.3168/jds.2015-10672.

Pires, J. A., C. Delavaud, Y. Faulconnier, D. Pomiès, and Y. Chilliard. 2013. Effects of body condition score at calving on indicators of fat and protein mobilization of periparturient Holstein-Friesian cows. J. Dairy Sci. 96:6423-6439. https://doi.org/10.3168/jds.2013 $-6801$.

Rico, J. E., V. R. Bandaru, J. M. Dorskind, N. J. Haughey, and J. W. McFadden. 2015. Plasma ceramides are elevated in overweight Holstein dairy cows experiencing greater lipolysis and insulin resistance during the transition from late pregnancy to early lactation. J. Dairy Sci. 98:7757-7770. https://doi.org/10.3168/jds.2015 $-9519$.

Roche, J. R., S. Meier, A. Heiser, M. D. Mitchell, C. G. Walker, M. A. Crookenden, M. Vailati Riboni, J. J. Loor, and J. K. Kay. 2015 Effects of precalving body condition score and prepartum feeding level on production, reproduction, and health parameters in pasture-based transition dairy cows. J. Dairy Sci. 98:7164-7182. https://doi.org/10.3168/jds.2014-9269.

Ruprechter, G., M. L. Adrien, A. Larriestra, O. Meotti, C. Batista, A Meikle, and M. Noro. 2018. Metabolic predictors of peri-partum diseases and their association with parity in dairy cows. Res Vet Sci. 118:191-198. https://doi.org/10.1016/j.rvsc.2018.02.005.

Salin, S., A. Vanhatalo, K. Elo, J. Taponen, R. C. Boston, and T. Kokkonen. 2017. Effects of dietary energy allowance and decline in dry matter intake during the dry period on responses to glucose and insulin in transition dairy cows. J. Dairy Sci. 100:5266-5280. https: //doi.org/10.3168/jds.2016-11871.

Han van der Kolk, J. H., J. J. Gross, V. Gerber, and R. M. Bruckmaier. 2017. Disturbed bovine mitochondrial lipid metabolism: A review. Vet. Q. 37:262-273.

Wathes, D. C., Z. Cheng, N. Bourne, V. J. Taylor, M. P. Coffey, and S. Brotherstone. 2007. Differences between primiparous and multiparous dairy cows in the inter-relationships between metabolic traits, milk yield and body condition score in the periparturient period. Domest. Anim. Endocrinol. 33:203-225. https://doi.org/10.1016/j .domaniend.2006.05.004 
Weber, C., C. Hametner, A. Tuchscherer, B. Losand, E. Kanitz, W. Otten, H. Sauerwein, R. M. Bruckmaier, F. Becker, W. Kanitz, and H. M. Hammon. 2013b. Hepatic gene expression involved in glucose and lipid metabolism in transition cows: Effects of fat mobilization during early lactation in relation to milk performance and metabolic changes. J. Dairy Sci. 96:5670-5681. https://doi .org/10.3168/jds.2012-6277.

Weber, C., C. Hametner, A. Tuchscherer, B. Losand, E. Kanitz, W. Otten, S. P. Singh, R. M. Bruckmaier, F. Becker, W. Kanitz, and H. M. Hammon. 2013a. Variation in fat mobilization during early lactation differently affects feed intake, body condition, and lipid and glucose metabolism in high-yielding dairy cows. J. Dairy Sci. 96:165-180. https://doi.org/10.3168/jds.2012-5574.

Weber, C., C. T. Schäff, U. Kautzsch, S. Börner, S. Erdmann, R. M. Bruckmaier, M. Röntgen, B. Kuhla, and H. M. Hammon. 2017. Variable liver fat concentration as a proxy for body fat mobili- zation postpartum has minor effects on insulin-induced changes in hepatic gene expression related to energy metabolism in dairy cows. J. Dairy Sci. 100:1507-1520. https://doi.org/10.3168/jds .2016-11808.

Weber, C., C. T. Schäff, U. Kautzsch, S. Börner, S. Erdmann, S. Görs, M. Röntgen, H. Sauerwein, R. M. Bruckmaier, C. C. Metges, B. Kuhla, and H. M. Hammon. 2016. Insulin-dependent glucose metabolism in dairy cows with variable fat mobilization around calving. J. Dairy Sci. 99:6665-6679. https://doi.org/10.3168/jds .2016-11022

Zachut, M., H. Honig, S. Striem, Y. Zick, S. Boura-Halfon, and U. Moallem. 2013. Periparturient dairy cows do not exhibit hepatic insulin resistance, yet adipose-specific insulin resistance occurs in cows prone to high weight loss. J. Dairy Sci. 96:5656-5669. https: //doi.org/10.3168/jds.2012-6142. 